\title{
Latar Pendidikan Dewan Direksi, Dewan Komisaris, Komite Audit dan Praktik Manajemen Laba Riil
}

\author{
Putu Mira Hasta Andira1 \\ Ni Made Dwi Ratnadi² \\ 1,2Fakultas Ekonomi dan Bisnis Universitas Udayana, Indonesia. \\ *Correspondences: mirahasta@gmail.com
}

\begin{abstract}
ABSTRAK
Manajemen laba merupakan suatu bentuk tindakan oportunis yang dilakukan oleh manajer untuk mencapai tujuan tertentu. Tujuan penelitian ini adalah untuk mengetahui pengaruh latar pendidikan dewan direksi, dewan komisaris dan komite audit pada manajemen laba riil. Penelitian ini dilakukan di Perusahaan Manufaktur yang terdaftar di Bursa Efek Indonesia (BEI) menggunakan metode purposive sampling. Teknik analisis yang digunakan adalah regresi linear berganda. Berdasarkan hasil analisis ditemukan bahwa latar pendidikan akuntansi dan keuangan yang dimiliki oleh dewan direksi, dewan komisaris dan komite audit berpengaruh negatif pada manajemen laba riil dalam perusahaan. Hasil penelitian juga menunjukkan bahwa latar belakang pendidikan akuntansi dan keuangan merupakan salah satu faktor yang dapat mencegah terjadinya manajemen laba dalam perusahaan.
\end{abstract}

Kata Kunci: Manajemen Laba Riil; Pendidikan; Dewan Direksi; Dewan Komisaris; Komite Audit.

\section{Educational Background of the Board of Directors, Board of Commissioners, Audit Committee and Real Earnings Management Practices}

\section{ABSTRACT}

Earnings management is a form of opportunistic action taken by managers to achieve certain goals. The purpose of this study was to determine the effect of the educational background of the board of directors, board of commissioners and audit committee on real earnings management. This research was conducted in a manufacturing company listed on the Indonesia Stock Exchange (IDX) using purposive sampling method. The analysis technique used is multiple linear regression. Based on the results of the analysis, it was found that the educational background of accounting and finance owned by the board of directors, board of commissioners and audit committee had a negative effect on real earnings management in the company. The results also show that the educational background of accounting and finance is one of the factors that can prevent the occurrence of earnings management in the company.

Keywords: Real Earning Management; Education; Board Of Director; Board Of Commissioner; Audit Committee.

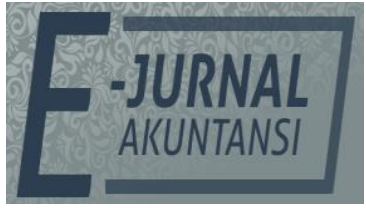

e-ISSN 2302-8556

Vol. 32 No. 1

Denpasar, Januari 2022

Hal. 155-167

DOI:

10.24843/EJA.2022.v32.i01.p11

PENGUTIPAN:

Andira, P. M. H. \& Ratnadi, N. M. D. (2022). Latar

Pendidikan Dewan Direksi,

Dewan Komisaris, Komite Audit dan Praktik

Manajemen Laba Riil. EJurnal Akuntansi, 32(1),

155-167

RIWAYAT ARTIKEL: Artikel Masuk:

(Diisi Tanggal Submit) Artikel Diterima: 31 Desember 2019

Artikel dapat diakses : https://ojs.unud.ac.id/index.php/Akuntansi/index 


\section{PENDAHULUAN}

Informasi mengenai laba akuntansi merupakan salah satu faktor penting untuk menilai kinerja perusahaan (Eugster \& Wagner, 2021). Laba akuntansi merupakan salah satu indikator yang digunakan untuk mengukur kinerja manajer dalam perusahaan (Sari \& Meiranto, 2017). Investor memiliki kecenderungan untuk melihat angka laba yang tercantum tanpa memperhatikan proses pencapaian laba tersebut (Yogi \& Damayanthi, 2016). Latar belakang tersebut menimbulkan keinginan manajer untuk melakukan tindakan oportunistik demi keuntungan pribadinya. Manajer juga dapat melihat adanya kesempatan yang menimbulkan keinginan untuk melakukan tindakan oportunistik.

Akuntansi berbasis akrual memiliki keunggulan dalam hal waktu (time period) namun pada saat bersamaan metode ini membuka peluang bagi manajer dalam menentukan metode akuntansi yang digunakan. Hal tersebut diijinkan selama metode tersebut tidak menyimpang dari Standar Akuntansi yang berlaku (Sutapa \& Suputra, 2016). Celah tersebut dimanfaatkan oleh manajer untuk melakukan tindakan oportunistik. Tindakan oportunistik manajer dalam memanipulasi laporan keuangan dapat dilakukan melalui praktik manajemen laba.

Manajemen laba merupakan suatu tindakan manajer dalam pemilihan keputusan ataupun tindakan akuntansi yang memengaruhi laba, dalam rangka untuk mencapai tujuan pelaporan laba tertentu (Scott, 2011). Manajemen laba menyebabkan kredibilitas suatu laporan keuangan menurun. Laporan keuangan yang mengandung manajemen laba dapat menyebabkan bias dalam laporan keuangan serta dapat menurangi reliabilitas dan relevansi yang dapat mengganggu pengguna laporan keuangan dalam mempercayai angka hasil rekayasa tersebut sebagai angka yang tidak direkayasa (Oraby, 2017).

Manajemen laba oleh manajer dapat dilakukan melalui dua metode, yaitu manajemen laba berbasis akrual dan manajemen laba berbasis riil. Manajer lebih suka untuk melakukan manajemen laba riil (Subekti, 2012). Manipulasi laba berbasis riil dapat disembunyikan dalam aktivitas perusahaan sehari-hari dalam periode akuntasi tertentu sehingga lebih sulit untuk dideteksi oleh regulator serta auditor (Sarra \& Bannouri, 2015).

Praktik manajemen laba riil lebih berbahaya dan beresiko apabila dibandingkan dengan manajemen laba berbasis akrual karena dapat memengaruhi keputusan bisnis serta arus kas secara langsung (Khanh \& Khuong, 2018). Manajemen laba riil juga lebih sulit dideteksi karena dapat disembunyikan dalam aktivitas bisnis normal (Anagnostopoulou \& Tsekrekos, 2017).

Upaya manajemen laba dapat dicegah dengan adanya corporate governance dalam perusahaan. Sejak krisis ekonomi tahun 1998, Indonesia mulai menyadari betapa pentingnya tata kelola perusahaan (corporate governance) bagi perekonomian (Dewi, 2017). Salah satu aspek corporate governance yang perlu dilaksanakan ialah adanya mekanisme corporate governance yang baik. Mekanisme corporate governance tersebut terdiri atas dewan direksi, dewan komisaris dan komite audit.

Salah satu isu terkait mekanisme corporate governance ialah adanya board diversity. Diversitas dalam aspek corporate governance dapat diartikan sebagai komposisi dari dewan direksi dan komisaris serta kombinasi dari kualitas, 
kemampuan serta karakteristik dari masing-masing individu yang berbeda dalam hal yang berkaitan dengan pengambilan keputusan maupun kegiatan lainnya yang dilaksanakan oleh dewan perusahaan (Lückerath-Rovers, 2012).

Salah satu aspek kognitif dalam diversitas dewan adalah latar belakang pendidikan. Latar pendidikan memegang peranan penting dalam menilai kemampuan seseorang karena dari latar pendidikan dapat diketahui seberapa besar pengetahuan serta kompetensi yang dimiliki oleh seseorang (Hodgman, 2018). Latar belakang pendidikan seseorang juga dapat memengaruhi kinerja orang tersebut, sehingga diperlukan seorang karyawan yang memiliki latar belakang sesuai dengan bidang pekerjaannya (Setiawan, 2015). Pendidikan juga berperan untuk mempersiapkan sumber daya manusia (SDM) untuk memasuki dunia kerja karena cara seseorang berbicara maupun bersikap akan sesuai dengan pendidikan yang mereka miliki (Dini \& Sari, 2013). Latar belakang pendidikan dari struktur organisasi perusahaan dapat memengaruhi proses serta hasil pengambilan keputusan. Efektivitas fungsi struktur organisasi dalam perusahaan haruslah didukung dengan kompetensi yang memadai.

Penelitian yang dilakukan sebelumnya menemukan bahwa akuntan "tidak berkembang secara etis" yang memiliki arti bahwa akuntan "terjebak" dalam gaya penalaran etika yang konvensional mengenai ketaatan terhadap norma, kode etik dan aturan (Hu et al., 2017). Gaya penalaran etika yang konvensional merupakan sesuatu yang sebenarnya diharapkan dimiliki oleh seorang akuntan, akuntan dituntut untuk bersikap "kaku" dan taat pada peraturan karena segala aktivitas akuntan diatur dalam standar yang mengikat, dimana salah satu aturan dasar dalam akuntansi ialah Generally Accepted Accounting Principals (GAAP) yang merupakan standar akuntansi umum berbasis aturan.

Penelitian ini mengacu pada teori agensi yang dikemukakan oleh (Jensen \& Meckling, 1976). Teori agensi menjelaskan hubungan antara agen (manajer) dan prinsipal (pemegang saham). Pemisahan wewenang sebagai pemilik dan pengelola perusahaan dilakukan untuk meningkatkan efisiensi dalam usaha meningkatkan keuntungan perusahaan. Namun, pemisahan fungsi antara pemilik dan pengelola ini menimbulkan suatu konflik karena adanya perbedaan kepentingan antara prinsipal dan agen. Perbedaan kepentingan tersebut menimbulkan keinginan bagi agen untuk melakukan tindakan oportunistis yang menguntungkan dirinya sendiri, ditambah lagi agen memiliki akses informasi yang lebih baik dibandingkan prinsipal dalam perusahaan. Keadaan ini menyebabkan timbulnya asimetri informasi antara pihak agen dan prinsipal. Perbedaan kepentingan dan asimetri informasi antara pihak agen dan prinsipal menyebakan timbulnya biaya agensi.

Teori agensi menyatakan bahwa agency cost dapat dikurangi dengan mekanisme pengawasan yang tepat oleh perusahaan. Mekanisme pengawasan yang dimaksud di dalam teori agensi adalah melalui mekanisme corporate governance. Mekanisme corporate governance tersebut diantaranya adalah dewan direksi, dewan komisaris dan komite audit. Pemilihan anggota dewan direksi, dewan komisaris dan komite audit secara teliti sangat penting untuk dilakukan karena dapat memengaruhi keputusan yang dibuat oleh perusahaan serta kelangsungan hidup perusahaan. 
Teori ketergantungan sumber daya yang dikemukakan oleh Aldrich dan Pfeffer juga mendukung penelitian ini. Teori ketergantungan sumber daya menyatakan bahwa organisasi harus mampu mengelola segala bentuk sumber daya manusia yang dimiliki secara maksimal. Hal tersebut dapat mendorong perusahaan untuk meningkatkan kinerja serta mendorong perusahaan untuk mencapai kemakmuran (Mitchell et al., 2001). Teori ketergantungan sumber daya menyiratkan bahwa kualitas sumber daya manusia dalam perusahaan adalah salah satu aset penting bagi perusahaan. Dewan direksi, dewan komisaris serta komite audit merupakan sumber daya manusia yang harus dikelola oleh perusahaan secara maksimal. Sumber daya manusia yang dipilih untuk memegang peranan tersebut harus berkualitas agar dapat menjamin masa depan perusahaan. Salah satu aspek yang perlu diperhatikan dalam memilih anggota dewan ialah latar pendidikan. Seseorang yang memiliki latar belakang pendidikan dalam bidang akuntansi dan keuangan memiliki keunggulan dalam memahami laporan keuangan perusahaan. Kemampuan dalam bidang akuntansi dan keuangan dapat membantu dewan direksi, dewan komisaris dan komite audit untuk mencegah manajer di bawahnya melakukan tindakan oportunistik.

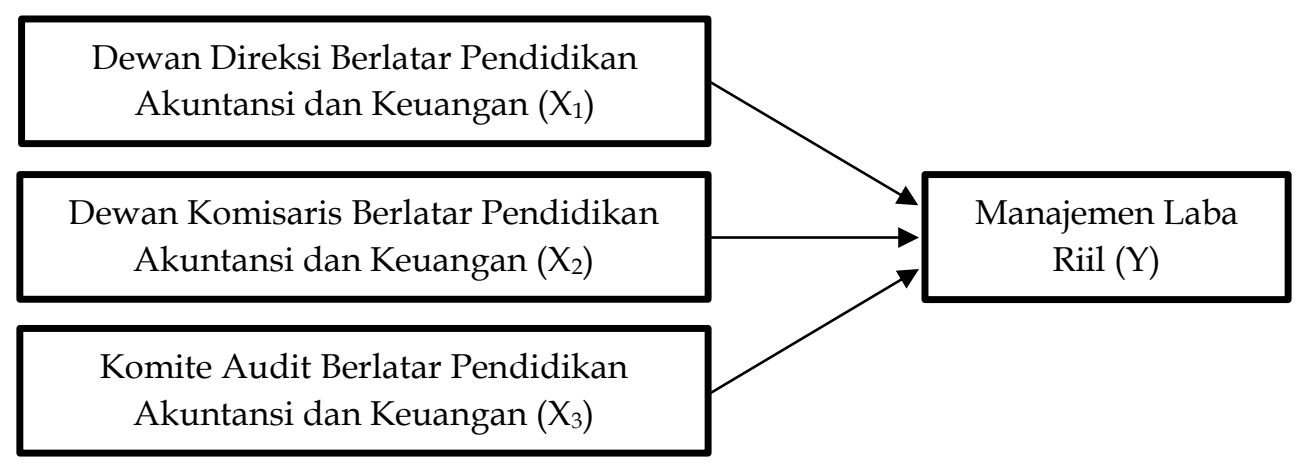

Sumber: Data Penelitian, 2021

\section{Gambar 1. Model Penelitian}

Dalam teori agensi disebutkan bahwa adanya pendelegasian wewenang dari pemilik kepada manajer menyebabkan kemungkinan terjadinya masalah agensi salah satunya ialah asimetri informasi. Di Indonesia, dewan direksi memegang fungsi sebagai "agen" dalam perusahaan yang bertanggung jawab sebagai pihak yang mengelola serta mengambil keputusan dalam perusahaan. Berdasarkan teori ketergantungan sumber daya, perusahaan yang mampu mengelola sumber daya perusahaan secara maksimal akan mengantarkan perusahaan pada kesuksesan. Salah satu sumber daya penting bagi perusahaan ialah sumber daya manusia. Pemilihan sumber daya manusia yang tepat dapat mempengaruhi kinerja dan kesuksesan suatu perusahaan. Sebab itulah pemilihan anggota dewan direksi merupakan hal yang sangat penting bagi perusahaan karena dapat mempengaruhi keputusan yang dibuat untuk perusahaan. Pengambilan keputusan bisnis dilakukan lebih baik dan akurat oleh anggota dewan yang memiliki latar belakang pendidikan akuntansi dan keuangan (Ying \& $\mathrm{He}, 2020)$. Penelitian sebelumnya menemukan bahwa orang berlatar pendidikan akuntansi dan keuangan cenderung lebih taat kepada aturan dibandingkan orangorang pada umumnya, hal ini merupakan sikap yang diharapkan dari seorang 
akuntan karena segala aktivitas akuntan dibatasi oleh standar yang mengikat contohnya seperti Generally Accepted Accounting Principals (GAAP) yang merupakan standar akuntansi umum berbasis aturan. Perilaku manajemen laba merupakan perilaku yang tidak sesuai dengan aturan yang berlaku karena dapat menyebabkan bias dalam laporan keuangan (Hu et al., 2017). Penelitian yang dilakukan oleh Xiong (2016) menunjukkan bahwa dewan direksi yang memiliki pendidikan dalam bidang akuntansi dan keuangan berpengaruh negatif pada praktik manajemen laba riil dalam perusahaan. Berdasarkan uraian tersebut, maka hipotesis yang diajukan dalam penelitian ini:

$\mathrm{H}_{1}$ : Keberadaan dewan direksi berlatar pendidikan akuntansi dan keuangan berpengaruh negatif pada praktik manajemen laba riil.

Teori agensi menyebutkan bahwa keberadaan dewan komisaris dianggap dapat mengurangi biaya agensi yang terjadi dalam perusahaan karena dengan adanya dewan komisaris selaku pengawas dalam perusahaan diharapkan dapat mengurangi adanya asimetri informasi antara pihak manajer dan pemilik saham (Zaitul, et al., 2019). Keberadaan dewan komisaris yang bekerja dengan baik dan efisien dapat meningkatkan kualitas laporan keuangan perusahaan (Setiawan, 2018). Dewan komisaris memiliki tanggung jawab dalam mengawasi setiap pelaporan keuangan yang dilakukan oleh perusahaan melalui pertemuan rutin yang diadakan oleh dewan komisaris dengan auditor eksternal dan accounting staff untuk melakukan review atas laporan keuangan, prosedur audit dan mekanisme pengendalian internal (Dwiharyadi, 2017). Pemilihan anggota dewan komisaris merupakan salah satu faktor yang penting dalam perusahaan karena sumber daya manusia yang berkualitas dapat meningkatkan kinerja perusahaan. Hal tersebut sesuai dengan teori ketergantungan terhadap sumber daya dimana disebutkan bahwa perusahaan yang mampu mengelola sumber daya eksternal dengan baik akan menghantarkan perusahaan pada tujuannya. Salah satu faktor yang dapat dilihat dalam memilih anggota dewan komisaris adalah latar belakang pendidikan akuntansi dan keuangan. Dewan komisaris yang memiliki latar belakang pendidikan dalam bidang akuntansi dan keuangan dapat meningkatkan kualitas keputusan yang diambil oleh perusahaan karena pemahaman yang lebih mendalam di bidang keuangan serta mampu memperketat pengawasan dewan komisaris terhadap kinerja dewan direksi (Honesty, 2019). Xi et al. (2003) menemukan bahwa praktik manajemen laba cenderung jarang terjadi dalam perusahaan-perusahaan yang memiliki dewan komisaris yang memiliki latar belakang keuangan. Penelitian yang dilakukan oleh Amin et al. (2017) menemukan bahwa dewan komisaris yang memiliki latar pendidikan akuntansi dan keuangan berpengaruh negatif pada manajemen laba perusahaan. Maka dari uraian tersebut, hipotesis dalam penelitian ini.

$\mathrm{H}_{2}$ : Keberadaan dewan komisaris berlatar pendidikan akuntansi dan keuangan berpengaruh negatif pada praktik manajemen laba riil.

Komite audit merupakan suatu komite yang dibentuk oleh dewan komisaris yang memiliki fungsi untuk membantu tugas dewan komisaris dalam melakukan pengawasan terhadap laporan keuangan perusahaan. Adanya komite audit juga dapat mengatasi masalah agensi. Komite audit yang dibentuk untuk membantu dewan komisaris dalam melakukan pengawasan terhadap laporan keuangan dapat memperketat dan meningkatkan pencegahan tindakan 
oportunistis oleh manajer. The Sarbanes Oxley Act of 2002 (SOX) juga menekankan betapa pentingnya peran komite audit terhadap kualitas laporan keuangan (Badolato et al., 2014).

Peraturan Otoritas Jasa Keuangan (POJK) mengenai pelaksanaan kerja komite audit menyebutkan bahwa dalam perusahaan wajib memiliki paling sedikit 1 (satu) orang anggota komite audit yang berlatar pendidikan dan memiliki keahlian dalam bidang akuntansi dan keuangan. Keahlian dalam bidang akuntansi dan keuangan dianggap penting dalam mewujudkan efektivitas kerja komite audit karena tugas komite audit yang memerlukan keahlian dalam bidang tersebut dengan baik demi melindungi kepentingan pemegang saham (Zaman, Hudaib \& Haniffa, 2011). Penelitian ini didukung oleh penelitian lain yang menemukan bahwa keahlian akuntansi dan keuangan yang dimiliki oleh anggota komite audit dapat mengurangi terjadinya praktik manajemen laba perusahaan (Widasari \& Isgiyarta, 2017). Penelitian lain juga menemukan bahwa kompentensi komite audit berpengaruh negatif pada praktik manajemen laba riil perusahaan (Yuliani \& Dewi, 2015).

$\mathrm{H}_{3}$ : Keberadaan komite audit berlatar pendidikan akuntansi dan keuangan berpengaruh negatif pada praktik manajemen laba riil.

\section{METODE PENELITIAN}

Penelitian ini menggunakan metode purposive sampling dalam melakukan penentuan sampel. Penelitian ini juga menggunakan teknik analisis regresi dengan alat analisis yaitu regresi linear berganda. Objek penelitian ini adalah manajemen laba riil perusahaan sektor manufaktur yang terdaftar di Bursa Efek Indonesia pada tahun 2017 -2018. Populasi dalam penelitian ini diperoleh sebanyak 157 perusahaan yang diseleksi dengan kriteria: (1) perusahaan manufaktur yang terdaftar di Bursa Efek Indonesia berturut-turut pada tahun 2017-2018; (2) perusahaan manufaktur yang mempublikasikan laporan keuangan tahun 2015-2018 berturut-turut; (3) perusahaan manufaktur yang menggunakan mata uang rupiah dalam laporan keaungan tahun 2015-2018. Berdasarkan kriteria tersebut sebanyak 98 perusahaan digunakan sebagai sampel dalam penelitian ini.

Dewan Direksi merupakan organ perseroan yang memiliki tanggung jawab mengelola perseroan sesuai dengan maksud dan tujuan perseroan. Dewan direksi merupakan organ yang penting dalam proses pengambilan keputusan dalam perseroan. Pemahaman mendalam dalam akuntansi dan keuangan akan membantu dewan direksi dalam memahami laporan keuangan yang lebih baik. Dewan direksi berlatar pendidikan akuntansi dan keuangan $\left(X_{1}\right)$ diukur dengan cara berikut.

$$
X_{1}=\frac{\text { Dewan direksi berlatar pendidikan akuntansi dan keuangan }}{\text { total dewan direksi }} \times 100 \% \text {. }
$$

Dewan Komisaris merupakan organ perseroan yang memiliki fungsi selaku pengawas serta pemberi nasehat sesuai dengan tujuan perusahaan. Pemahaman mengenai akuntansi dan keuangan yang mendalam akan membantu dewan komisaris untuk melakukan pengawasan dalam perusahaan. Dewan komisaris berlatar pendidikan akuntansi dan keuangan $\left(\mathrm{X}_{2}\right)$ diukuR dengan cara berikut.

$$
\mathrm{X}_{2}=\frac{\text { Dewan komisaris berlatar pendidikan akuntansi dan keuangan }}{\text { total dewan komisaris }} \times 100 \%
$$


Komite audit merupakan suatu organ perseroan yang dibentuk untuk membantu dewan komisaris dalam melakukan pengawasan dalam perusahaan khususnya dalam mengawasi laporan keuangan perusahaann. Pendidikan akuntansi dan keuangan wajib untuk dimiliki oleh minimal 1(satu) orang komite audit karena latar pendidikan keuangan penting dimiliki untuk melaksanakan tugas selaku pengawas laporan keuangan. Komite audit berlatar pendidikan akuntansi dan keuangan $\left(X_{3}\right)$ diukur dengan cara berikut.

$$
\mathrm{X}_{3}=\frac{\text { Komite audit berlatar pendidikan akuntansi dan keuangan }}{\text { total komite audit }} \times 100 \%
$$

Perhitungan proksi manajemen laba riil diukur menggunakan model estimasi dari Subekti (2012). Penyesuaian dilakukan dengan mengubah total asset $\left(1 / A_{t-1}\right)$ menjadi logaritma untuk asset $\left(1 /\right.$ Log. $\left.A_{t-1}\right)$. Hal ini dilakukan untuk menyesuaikan dengan perekonomian Indonesia sehingga mendapatkan hasil analisis yang lebih baik. Berikut merupakan rumus untuk menghitung manajemen laba riil.

$\operatorname{MLR}(\mathrm{Y})=\mathrm{AbnCFO}+\mathrm{AbnDISEXP}+(\mathrm{AbnPROD} \times(-1))$

Abnormal Cashflows Operation (AbnCFO) adalah bentuk manajemen laba dimana manipulasi laba yang dilakukan melalui arus kas operasi. AbnCFO dapat dihitung dengan rumus sebagai berikut.

$$
A b n C F O=\frac{C F O t}{A t-1}-\left[\alpha 1\left(\frac{1}{\log \cdot A t-1}\right)+\beta 1\left(\frac{S t}{A t-1}\right)+\beta 2\left(\frac{\Delta S t}{A t-1}\right)\right] .
$$

Abnormal Discretionary Expenses (AbnDISEXP) adalah bentuk manajemen laba dimana manipulasi laba yang dilakukan melalui biaya diskresioner seperti biaya penjualan, biaya iklan, biaya lain-lain dan sebagainya. AbnDISEXP dapat dihitung dengan rumus sebagai berikut.

$$
A b n D I S E X P=\frac{\text { DISEXPt }}{A t-1}-\left[\alpha 1\left(\frac{1}{\text { Log.At-1 }}\right)+\beta 1\left(\frac{S t}{A t-1}\right)\right]
$$

Abnormal Production Cost (AbnPROD) adalah bentuk manajemen laba dimana manipulasi laba yang dilakukan melalui biaya produksinya. AbnPROD dapat dihitung dengan rumus sebagai berikut.

$$
\begin{aligned}
& A b n P R O D=\frac{P R O D t}{A t-1}-\left[\alpha 1\left(\frac{1}{\log \cdot A t-1}\right)+\beta 1\left(\frac{S t}{A t-1}\right)+\beta 2\left(\frac{\Delta S t}{A t-1}\right)+\right. \\
& \beta 3\left(\frac{\Delta S t-1}{A t-1}\right)
\end{aligned}
$$

Keterangan:

$$
\begin{array}{ll}
\text { MLR } & =\text { Manajemen laba riil } \\
\text { CFOt } & =\text { Arus kas kegiatan operasi perusahaan i pada tahun } \mathrm{t} \\
\text { PRODt } & =\text { Biaya produksi tahun } \mathrm{t} \text {, yaitu } \mathrm{HPP}+\Delta \text { Persediaan } \\
\mathrm{DISEXPt} & =\text { Biaya diskresioner perusahaan i pada tahun } \mathrm{t} \\
\mathrm{A}_{\mathrm{t}-1} & =\text { Total aktiva perusahaan i pada tahun } \mathrm{t} \\
\mathrm{St} & =\text { Penjualan perusahaan i pada tahun } \mathrm{t} \\
\Delta \mathrm{St} & =\text { Penjualan perusahaan i pada tahun dikurangi tahun } \mathrm{t}-1 \\
\Delta \mathrm{St}-1 & =\text { Penjualan perusahaan i pada tahun } \mathrm{t}-1 \text { dikurangi tahun } \mathrm{t}-2 \\
\mathrm{a}_{0}, \mathrm{a}_{1}, \mathrm{a}_{2}, \beta_{1}, \beta_{2}, \beta_{3} & =\text { Koefisien regresi } \\
\varepsilon & =\text { Error term pada tahun } \mathrm{t}
\end{array}
$$

\section{HASIL DAN PEMBAHASAN}

Statistik deskriptif bertujuan untuk memberikan informasi mengenai karakteristik dari variabel penelitian terkait dengan nilai minimum, nilai maksimum, nilai mean, 
dan standar deviasi. Nilai sentral dari distribusi data dapat dilakukan dengan pengukuran rata-rata sedangkan deviasi standar menggambarkan besaran sebaran data terhadap nilai rata-ratanya. Hasil statistik deskriptif dapat dilihat pada Tabel 1.

Tabel 1. Hasil Statistik Deskriptif

\begin{tabular}{lccccc}
\hline & $\mathrm{N}$ & Minimum & Maximum & Mean & Std.Deviasi \\
\hline Manajemen Laba Riil & 196 & $-29,33$ & 3,69 & $-0,37$ & 2,36 \\
Dewan Direksi & 196 & 0,00 & 1,00 & 0,62 & 0,22 \\
Dewan Komisaris & 196 & 0,00 & 1,00 & 0,55 & 0,29 \\
Komite Audit & 196 & 0,25 & 1,00 & 0,82 & 0,23 \\
Valid N (listwise) & 196 & & & &
\end{tabular}

Sumber: Data Penelitian, 2020

Berdasarkan hasil uji statistik diperoleh sebanyak 196 data observasi yang berasal dari perkalian antara periode penelitian dengan jumlah sampel perusahaan yaitu 98 perusahaan sampel dalam 2 tahun pengamatan. Berdasarkan hasil statistik deskriptif dengan jumlah data sebanyak 196 diperoleh nilai minimum sebesar $-29,22$, sedangkan nilai maksimum sebesar 3,69. Nilai rata-rata manajemen laba riil sebesar -0,37. Rata-rata manajemen laba bernilai negatif menandakan rata-rata perusahaan manufaktur cenderung melakukan manajemen laba dengan pola menurunkan laba (income decreasing). Deviasi standar manajemen laba riil adalah sebesar 2,36. Nilai deviasi standar yang lebih besar dari nilai rata-ratanya menandakan data yang digunakan sebagai sampel memiliki sebaran data yang besar atau bervariasi.

Nilai minimum persentase dewan direksi berlatar pendidikan akuntansi dan keuangan adalah 0,00 dan nilai maksimumnya adalah 1,00. Nilai mean untuk variabel dewan direksi berlatar pendidikan akuntansi dan keuangan adalah 0, 62 . Rata-rata nilai dewan direksi berlatar pendidikan akuntansi dan keuangan lebih mendekati nilai maksimumnya menandakan rata-rata dewan direksi berlatar pendidikan akuntansi dan keuangan dalam perusahaan adalah tinggi. Deviasi standar dewan direksi berlatar pendidikan akuntansi dan keuangan sebesar 0,22. Nilai deviasi standar yang lebih rendah dari nilai rata-ratanya menandakan data yang digunakan sebagai sampel memiliki sebaran data yang rendah atau kurang bervariasi.

Nilai minimum persentase dewan komisaris berlatar pendidikan akuntansi dan keuangan adalah 0,00 dan nilai maksimumnya adalah 1,00. Nilai mean untuk variabel dewan komisaris berlatar pendidikan akuntansi dan keuangan adalah 0 , 55. Rata-rata nilai dewan komisaris berlatar pendidikan akuntansi dan keuangan lebih mendekati nilai maksimumnya menandakan rata-rata dewan direksi berlatar pendidikan akuntansi dan keuangan dalam perusahaan adalah tinggi. Deviasi standar persentase dewan komisaris berlatar pendidikan akuntansi dan keuangan sebesar 0,29. Nilai deviasi standar yang lebih rendah dari nilai rata-ratanya menandakan data yang digunakan sebagai sampel memiliki sebaran data yang rendah atau kurang bervariasi.

Nilai minimum persentase komite audit berlatar pendidikan akuntansi dan keuangan adalah 0,25 dan nilai maksimumnya adalah 1,00 . Nilai mean untuk variabel komite audit berlatar pendidikan akuntansi dan keuangan adalah 0,82. Rata-rata nilai komite audit berlatar pendidikan akuntansi dan keuangan lebih 
mendekati nilai maksimumnya menandakan rata-rata komite audit berlatar pendidikan akuntansi dan keuangan dalam perusahaan adalah tinggi. Deviasi standar persentase komite audit berlatar pendidikan akuntansi dan keuangan sebesar 0,23. Nilai deviasi standar yang lebih rendah dari nilai rata-ratanya menandakan data yang digunakan sebagai sampel memiliki sebaran data yang rendah atau kurang bervariasi.

Uji asumsi klasik bertujuan untuk memastikan bahwa model yang dibuat telah valid dan memenuhi asumsi-asumsi dasar dalam analisis regresi. Pengujian asumsi klasik pada penelitian ini meliputi uji normalitas, uji autokorelasi, uji multikolinearitas, dan uji heteroskedastisitas. Pada penelitian ini uji asumsi klasik dilakukan melalui software SPSS 23.0 for MAC OS dan menunjukkan hasil bahwa data penelitian yang digunakan telah lulus dalam uji asumsi klasik.

Analisis regresi linier berganda digunakan untuk mengetahui pengaruh variabel bebas pada variabel terikatnya. Perhitungan koefisien regresi linier berganda dilakukan dengan analisis regresi melalui software SPSS 23.0 for MAC OS, diperoleh hasil yang ditunjukan pada Tabel 2 sebagai berikut.

Tabel 2. Hasil Analisis Regresi Linier Berganda

\begin{tabular}{|c|c|c|c|c|c|}
\hline & \multicolumn{2}{|c|}{$\begin{array}{c}\text { Unstandardized } \\
\text { Coefficients }\end{array}$} & \multirow{2}{*}{$\begin{array}{l}\begin{array}{l}\text { Standardized } \\
\text { Coefficients } \\
\text { Beta }\end{array} \\
\end{array}$} & \multirow[t]{2}{*}{$\mathrm{t}$} & \multirow[t]{2}{*}{ Sig. } \\
\hline & $B$ & Std. Error & & & \\
\hline Konstanta & 0,04 & 0,05 & & 0,80 & 0,42 \\
\hline Dewan Direksi & $-0,16$ & 0,05 & $-0,20$ & $-3,05$ & 0,00 \\
\hline Dewan Komisaris & $-0,18$ & 0,06 & $-0,21$ & $-3,05$ & 0,00 \\
\hline Komite Audit & $-0,13$ & 0,05 & $-0,17$ & $-2,48$ & 0,01 \\
\hline Adjusted $R^{2}$ & 0,14 & & & & \\
\hline$F_{\text {hitung }}$ & 11,36 & & & & \\
\hline Sig. F & 0,00 & & & & \\
\hline
\end{tabular}

Sumber: Data Penelitian, 2020

Berdasarkan hasil analisis regresi linier berganda seperti yang disajikan pada Tabel 2, maka dapat dibuat persamaan regresi sebagai berikut:

Manajemen Laba Riil = 0,04 - 0,16Dewan Direksi - 0,18Dewan Komisaris -

\section{0,13Komite Audit}

Nilai konstanta 0,04 menunjukan jika persentase dewan direksi berpendidikan akuntansi dan keuangan, persentase dewan komisaris berpendidikan akuntansi dan keuangan dan persentase komite audit berpendidikan akuntansi dan keuangan sama dengan nol, maka manajemen laba riil akan naik sebesar 0,04 persen.

Nilai koefisien regresi dewan direksi berpendidikan akuntansi dan keuangan sebesar -0,16 menandakan jika persentase dewan direksi berpendidikan akuntansi dan keuangan naik satu persen, maka manajemen laba riil akan mengalami penurunan sebesar 0,16 persen dengan asumsi variabel lain konstan. Hasil ini sesuai dengan $\mathrm{H}_{1}$ dalam penelitian ini. Hasil ini sesuai dengan Resource Dependence Theory yang menjelaskan bahwa kualitas sumber daya eksternal perusahaan mampu memengaruhi kinerja suatu organisasi. Perusahaan yang memiliki dewan direksi berlatar belakang akuntansi dan keuangan memiliki kelebihan dalam memahami laporan keuangan. Kelebihan tersebut dapat membantu dewan direksi dalam memberikan saran kepada perusahaan serta 
mendeteksi tindakan oportunis yang mungkin dilakukan oleh manajer dibawahnya.

Nilai koefisien regresi dewan komisaris berpendidikan akuntansi dan keuangan sebesar -0,18 menandakan jika persentase dewan komisaris berpendidikan akuntansi dan keuangan naik satu persen, maka manajemen laba riil akan mengalami penurunan sebesar 0,18 persen dengan asumsi variabel lain konstan. Hasil ini sesuai dengan $\mathrm{H}_{2}$ dalam penelitian ini. Hasil yang didapatkan dari hipotesis kedua penelitian ini sesuai dengan teori agensi dimana dalam teori ini dijelaskan bahwa konflik kepentingan dan asimetri informasi dapat dikurangi dengan mekanisme pengawasan yang tepat. Adanya dewan komisaris sebagai pengawas dalam perusahaan dapat mencegah tindakan oportunis yang dapat dilakukan oleh manajer. Hasil ini juga sesuai dengan Resource Dependence Theory dimana dewan komisaris perusahaan merupakan salah satu sumber daya eksternal yang perlu dioperasikan oleh perusahan. Latar belakang pendidikan akuntansi dan keuangan yang dimiliki oleh dewan komisaris akan membantu dewan komisaris dalam melakukan pengawasan terhadap laporan keuangan perusahaan sehingga tindakan oportunis manajer dapat dicegah karena adanya pengawasan yang lebih ketat dari dewan komisaris.

Nilai koefisien regresi komite audit berpendidikan akuntansi dan keuangan sebesar -0,13 menandakan jika persentase komite audit berpendidikan akuntansi dan keuangan naik satu persen, maka manajemen laba riil akan mengalami penurunan sebesar 0,13 persen dengan asumsi variabel lain konstan. Hasil ini sesuai dengan $\mathrm{H}_{3}$ dalam penelitian ini. Hasil penelitian ini dapat membuktikan adanya teori agensi, dimana menurut teori agensi, biaya agensi dapat dikurangi dengan adanya mekanisme pengawasan yang tepat, komite audit merupakan salah satu bagian dari mekanisme pengwasan dalam perusahaan. Komite audit memiliki peran sebagai pengawas laporan keuangan yang memegang peranan penting dalam mengurangi agency cost yang timbul akibat adanya masalah agensi yakni asimetri informasi dan perbedaan kepentingan. Hasil ini juga sesuai dengan Resource Dependence Theory. Komite audit memegang peran untuk memabantu dewan komisaris dalam melakukan pengawasan. Komite audit yang memiliki latar pendidikan akuntansi dan keuangan tentu memiliki pemahaman yang lebih mendalam terhadap laporan keuangan sehingga komite audit yang memiliki latar pendidikan akuntansi dan keuangan dapat lebih mudah mendeteksi kecurangan apa yang dapat dilakukan oleh manajer. Pengawasan yang lebih ketat dari komite audit tentu dapat mencegah terjadinya manajemen laba oleh manajer.

\section{SIMPULAN}

Penelitian ini bertujuan untuk memeroleh bukti empiris dari pengujian pengaruh latar pendidikan akuntansi dan keuangan dewan direksi, latar pendidikan akuntansi dan keuangan dewan komisaris, latar pendidikan akuntansi dan keuangan komite audit dan manajemen laba riil. Dewan direksi berlatar pendidikan akuntansi dan keuangan berpengaruh negatif pada manajemen laba rill perusahaan manufaktur. Ketika jumlah dewan direksi berlatar pendidikan akuntansi dan keuangan tinggi, maka tindakan manajemen laba riil dalam perusahaan dapat dikurangi. Dewan komisaris berlatar pendidikan akuntansi dan 
keuangan berpengaruh negatif pada manajemen laba rill perusahaan manufaktur. Ketika jumlah dewan komisaris berlatar pendidikan akuntansi dan keuangan tinggi, maka tindakan manajemen laba riil dalam perusahaan dapat dikurangi. Komite audit berlatar pendidikan akuntansi dan keuangan berpengaruh negatif pada manajemen laba rill perusahaan manufaktur. Ketika jumlah komite audit berlatar pendidikan akuntansi dan keuangan tinggi, maka tindakan manajemen laba riil dalam perusahaan dapat dikurangi.

Keterbatasan dalam penelitian ini adalah Nilai adjusted $\mathrm{R}$ square pada penelitian ini sebesar 14 persen yang menandakan 14 persen variasi perubahan manajemen laba riil dapat dijelaskan oleh variabel bebas yang digunakan dalam penelitian ini. Sedangkan sisanya sebesar 86 persen dijelaskan oleh variabel lain yang tidak digunakan dalam penelitian ini. Melihat hasil adjusted $\mathrm{R}$ square yang relatif kecil, maka peneliti selanjutnya dapat menambah variabel bebas lain atau menggunakan aspek diversitas lain seperti diversitas gender, usia, ataupun ras. Selain itu, penelitian ini hanya berfokus pada latar pendidikan yang dimiliki oleh pihak pengelola perusahaan, sehingga peneliti selanjutnya dapat meneliti latar pendidikan yang dimiliki oleh struktur kepemilikan perusahaan seperti pemegang saham publik, pemegang saham institusional dan pemegang saham manajerial.

\section{REFERENSI}

Aldrich, H. E. and Pfeffer, J. (1976) Environment of Organizations, Annual Review of Sociology, 2, pp. 79-105. doi: 10.1146/annurev.so.02.080176.000455.

Amin, A. et al. (2017) Board-Auditor Interaction and Earnings Management: The Model of Company with Concentrated Ownership, Review of Integrative Business and Economic Research, 6(3), pp. 217-238.

Anagnostopoulou, S. C. and Tsekrekos, A. E. (2017) The Effect Of Financial Leverage On Real And Accrual-Based Earnings Management, Accounting and Business Research, 47(2), pp. 191-236. doi: 10.1080/00014788.2016.1204217.

Badolato, P. G., Donelson, D. C. and Ege, M. (2014) Audit Committee Financial Expertise and Earnings Management: The Role of Status, Journal of Accounting and Economics, 58(2-3), pp. 208-230. doi: 10.1016/j.jacceco.2014.08.006.

Dewi, L. G. K. (2017) Pengaruh Diversitas Dewan Komisaris dan Direksi Pada Tax Avoidance, E-Jurnal Akuntansi Universitas Udayana, 18, pp. 763-789.

Dini, E. S. and Sari, M. K. (2013) Pengaruh Latar Belakang Pendidikan Dan Pelatihan Terhadap Kinerja, Journal of Economic dan Economic Education, 2(1), pp. 59-66.

Dwiharyadi, A. (2017) Pengaruh Keahlian Akuntansi Dan Keuangan Komite Audit Dan Dewan Komisaris Terhadap Manajemen Laba, Jurnal Akuntansi dan Keuangan Indonesia, 14(1), pp. 75-93. doi: 10.21002/jaki.2017.05.

Eugster, F. and Wagner, A. F. (2021) Earning investor trust: The role of past earnings management, Journal of Business Finance and Accounting, 48(1-2), pp. 269-307. doi: 10.1111/jbfa.12477.

Hodgman, M. R. (2018) Employers Perspectives on the Performance of Higher 
Education Institutions in Preparing Graduates for the Workplace: A Review of the Literature, Business and Economic Research, 8(3), pp. 92-103. doi: 10.5296/ber.v8i3.13370.

Honesty, F. F. (2019) The Interaction Between Corporate Social Responsibility and Earnings Management Using Board Characteristics as Moderating Variable, Wahana Riset Akuntansi, 7(1), pp. 1415-1424.

$\mathrm{Hu}, \mathrm{N}$. et al. (2017) The Impact of CEOss Accounting Backgrounds on Earnings Management and Conservatism, Journal of Centrum Cathedra a: The Business andEconomics Research Journal, 10(1), pp. 4-24. doi: 10.1108/jcc-102016-0016.

Jensen and Meckling (1976) Theory of the Firm: Managerial Behavior, Agency Costs and Ownership Structure, Journal of Financial Economics, 3(4), pp. 305-360.

Khanh, H. T. M. and Khuong, N. V. (2018) Audit Quality, Firm Characteristics and Real Earnings Management: The Case of Listed Vietnamese Firms, International Journal of Economics and Financial Issues, 8(4), pp. 243-249.

Lückerath-Rovers, M. (2012) Women on Board and Firm Performance, SSRN Electronic Journal. doi: 10.2139/ssrn.1586832.

Mitchell, T. et al. (2001) Why People Stay : Using Job Embeddedness to Predict Voluntary Turnover, Academy of Management Journal, 44(December), pp. 1102-1121. doi: 10.2307/3069391.

Oraby, S. A. (2017) The impact of earnings management on the value relevance of earnings, International Journal of Business and Social Science, 8(4), pp. 125135. doi: 10.1108/maj-01-2016-1304.

Sari, A. R. and Meiranto, W. (2017) Pengaruh Perilaku Opportunistik, Mekanisme Pengawasan, Dan Financial Distress Terhadap Manajemen Laba, Diponegoro Journal of Accounting, 6(4), pp. 67-83.

Sarra, E. and Bannouri, S. (2015) The Detection Of Real Earnings Management in MENA Countries: The Case Of Tunisia, Afro-Asian J. Finance and Accounting, 5(2), pp. 135-159. doi: 10.1504/ AAJFA.2015.069889.

Scott, R. W. (2011) Financial Accounting Theory 6th Edition, Toronto: Pearson Education. Canada.

Setiawan, D. (2018) Karakteristik dewan komisaris dan manajemen laba: Bukti pada peristiwa penawaran saham perdana Pendahuluan, Jurnal Siasat Bisnis, 22(2), pp. 164-181. doi: 10.20885/jsb.vol22.iss2.art4.

Setiawan, I. K. Y. (2015) Pengaruh Latar Belakang Pendidikan dan Pengalaman Kerja Terhadap Kinerja Karyawan Pada PT. Federal International Finance (FIF) Group Cabang Singaraja, Jurnal Jurusan Pendidikan Ekonomi (JJPE), 05(1), pp. 1-11.

Subekti, I. (2012) Accrual and Real Earning Management: One of The Perspective of Prospect Theory, Journal of Economics, Business, and Accountancy Ventura, 15(3), pp. 443-456.

Sutapa, I. N. and Suputra, I. D. G. D. (2016) Dampak Interaksi Asimetri Informasi terhadap Ukuran Perusahaan, Leverage dan Kompensasi pada Manajemen Laba, Jurnal Ekonomi dan Bisnis Universitas Udayana, 4(1), pp. 931-956.

Widasari, T. and Isgiyarta, J. (2017) Pengaruh Keahlian Komite Audit dan Jumlah 
Rapat Komite Audit terhadap Manajemen Laba dengan Audit Eksternal sebagai Variabel Moderasi, Pengaruh Keahlian Komite Audit Dan Jumlah Rapat Komite Audit Terhadap Manajemen Laba Dengan Audit Eksternal Sebagai Variabel Moderasi, 6(4), pp. 158-170.

Xie, B., Davidson, W. N. and Dadalt, P. J. (2003) Earnings Management and Corporate Governance: The Role of the Board and the Audit Committee, Journal of Corporate Finance, 9(3), pp. 295-316. doi: 10.1016/S09291199(02)00006-8.

Xiong, J. (2016) Chairman Characteristics and Earnings Management: Evidence from Chinese Listed Firms, Open Journal of Accounting, 5, pp. 82-94. doi: 10.4236/ ojacct.2016.54008.

Ying, Q. and He, S. (2020) Is the CEOs financial and accounting education experience valuable? Evidence from the perspective of $\mathrm{M} \& \mathrm{~A}$ performance, China Journal of Accounting Studies, 8(1), pp. 35-65. doi: 10.1080/21697213.2020.1822023.

Yogi, L. M. D. P. and Damayanthi, I. G. A. E. (2016) Pengaruh Arus Kas Bebas, Capital Adequacy Ratio dan Good Corporate Governance Pada Manajemen Laba, E-Jurnal Akuntansi Universitas Udayana, 15(2), pp. 10561085.

Yuliani and Dewi, C. N. (2015) Efektivitas Komite Audit dan Manajemen Laba Riil, Jurnal Riset Akuntansi dan Keuangan, 11.

Zaitul, Elfiswandib and Ilonab, D. (2019) Board of Commissioners Involvement and Shareholders Wealth, International Journal of Recent Technology and Engineering, 8(2 Special Issue 9), pp. 484-490. doi: 10.35940/ijrte.B1107.0982S919.

Zaman, M., Hudaib, M. and Haniffa, R. (2011) Corporate Governance Quality, Audit Fees and Non-Audit Services Fees, Journal of Business Finance and Accounting, 38(1-2), pp. 165-197. doi: 10.1111/j.1468-5957.2010.02224.x. 